\title{
Elective Oncology Surgeries: Cancellations And Causes
}

\author{
Mayara Cedrim Santos ${ }^{1}$, Jussara De Lucena Alves ${ }^{2}$, Bruna Gabrielle De Souza \\ Costa $^{3}$, Simone Yuriko Kameo ${ }^{4}$ \\ ${ }^{I}$ Nurse, Surgical Department of University Hospital Professor Alberto Antunes. Federal University of Alagoas, \\ Maceió,Alagoas, Brazil \\ ${ }^{2}$ Nurse, Chemotherapy Ambulatory of University Hospital Professor Alberto Antunes. Federal University of \\ Alagoas, Maceió,Alagoas, Brazil, \\ ${ }^{3}$ Nurse, Chemotherapy Ambulatory of University Hospital Professor Alberto Antunes. Federal University of \\ Alagoas, Maceió,Alagoas, Brazil, \\ ${ }^{4}$ Nurse, Professor of Department of Health Education. Federal University of Sergipe, Lagarto, Sergipe, Brazil,
}

\begin{abstract}
The aim of this research was to identify the elective surgeries suspension rate and investigate the causes of its cancellation in general surgery service in highly complex hospital. Method: A descriptive, exploratory, prospective and quantitative study was conducted in a university hospital using data from scheduled and canceled elective surgeries in the period from July 2015 to July 2016, which were extracted from MV System. Results: 984 elective surgeries oncology were scheduled during one year, of which 423 (43.4\%) were canceled. $258(32.3 \%)$ cancellations occurred in the morning. The main reason for cancellation was related with the patient seen in 269 cases (63.6\%). Conclusion: The number of cancellations was high, and the suspensions can and should be controlled and restricted. It is recommended the awareness of everyone involved in such a situation to which seeks a reduction in suspension rates and subsequently joint efforts to implement measures to restrict the most of this event.
\end{abstract}

Key words: Perioperative nursing; Quality indicators; health care; Hospital administration.

\section{Introduction}

The cancer as a chronic degenerative disease may impose on patients and their families a great challenge to adapt. The prognosis and therapy to be chosen represent a threat to health and body integrity [1].

The surgery was the first treatment modality that significantly altered the course of a neoplasm [2] and is often a conflict for the individual, due to drastic changes in daily life and the possible changes in body image. Currently, over $60 \%$ of cancer patients are treated surgically, and surgery is also used in the diagnosis and staging of more than $90 \%$ of all cases of cancer [2]. The application of surgical techniques, radiotherapy, chemotherapy and biological treatment can result in curing over 50\% of patients diagnosed with cancer [3].

Surgical volume held annually has grown significantly. It is estimated that 187 and 281 million major surgeries were performed, based on data from 56 countries, representing approximately 1 surgery for every 25 people per year [4]. In recent decades, surgical techniques were quite improved, increasing the opportunities for treatment of complex pathologies. However, these advances have also increased, expressively, the potential of errors that can result in harm to the patient and lead to disability or death. [5]

In the organizational process of the surgical planning, nurses have license to manage the needs preoperatively, during the preparation of the patient. The analysis of the surgical program should be developed and carried out by a nurse on the day prior to surgery, since it knows the whole organizational structure of the operating room [6].

The surgical program must contain information that will be use in preparing these surgeries by anesthesia teams, nurses, surgeons, laboratories, center of material and sterilization and blood center. Any inconsistencies in this information may result in the cancellation of a surgical procedure, which can occur due to a request of surgeons, anesthesiologists, nurses or patients [5].

The nurse's role in the planning and routine management of the Surgical Center is cited by authors who support the computerization of the surgical schedule and the need for all suspended operations, should be rescheduled for the same day or week. This applies especially to cancer patients, focus of this research, which is extremely fragile [6].

The Ministry of Health of Brazil [7] defines the suspension rate of surgery by the number of canceled surgeries divided by the total of scheduled surgeries in a period of time and multiplied by 100 .

The cancellation of a surgical procedure brings with it numerous consequences. There are changes in the routine of the patient and the family, because from the moment they are informed of the need to go through surgery, they all need to reschedule their activities in order to adapt to this new event that will experience. Furthermore, there are changes in the administrative part of the hospital which expends time and material 
resources to perform both cancellation as a new schedule when necessary [8]. The costs from these occurrences are also considerable, therefore justified the concern with this problem [9]. It is necessary to determine the reasons for cancellation of procedures, especially in specialties related to oncology.

Among the reasons for the cancellation of surgeries, the absence of patients on the scheduled day receives focus by some authors [10]. Suspensions in error function in the schedule are also discussed and can be avoided by performing a better internal planning. These authors emphasize the need for supporting infrastructure to obtain reliable data that can be used by nurses to better management [10].

Some of the proposed changes to minimize the occurrence of surgery suspension are: schedule confirmations in a period close to the surgery; control and investigation of suspension reasons and periodic meetings to discuss and plan for future surgery [11].

It was shown at the University Hospital (HU) located in Maceio, Alagoas, numerous cancellations of oncological elective surgeries. Knowing the consequences of this phenomenon, it was decided to draw up this study to identify the elective surgeries suspension rate and investigate the causes of its cancellation in general surgery service in highly complex hospital.

\section{Materials and Method}

It is a descriptive, exploratory and prospective study with a quantitative approach, using the data in the electronic management system of clinical information, assistance, administrative, financial and strategic called SOUL MV Hospital, University Hospital, in the city of Maceio, Alagoas, Brazil.

The institution is a reference to the State of Alagoas, meet people from various parts of Brazil and serves several specialties with the Unified Health System (SUS) as their only source of funds for working capital. The center's team consists of doctors, nurses, physiotherapists, psychologists, nutritionists and social workers, who work together in the treatment of all patients.

The University Hospital (UH) is a teaching hospital, linked to the university whose mission is to provide vocational training, producing knowledge and provide health care to the community with emphasis on excellence, humanization and social commitment. Respecting the values of ethics, participatory management, humanization, quality and patient safety, socio-economic and environmental responsibility and transparency.

The HU of the Surgical Center Unit has nine operating rooms, which are small surgeries, medium and large companies in various specialties, monthly. This institution serves patients hospitalized or admitted for surgery clinic. The surgical program is developed in the period from 7 to 19 hours daily, Monday to Friday. Periods night, weekends and holidays are meant for emergencies and emergencies of patients already hospitalized in the institution.

The sample consisted of information registered in the MV system, patients treated at Alta Center Complexity in Oncology (CACON), which is inserted in $\mathrm{HU}$, and had their scheduled elective surgeries and canceled in the period July 2015 to July 2016. data collection took place between the months of June to August 2016.

Inclusion criteria were: elective cancer surgery scheduled and canceled, which were recorded and available on the MV system. Among the exclusion criteria, contemplated the oncological surgery of urgency and emergency and oncological surgeries that were not registered and available in MV system CACON.

The recommendations have been met in the National Health Council Resolution 466/12 dealing with research involving human subjects. The information was consolidated and analyzed using descriptive statistics, with absolute and relative numbers, using statistical tools. The results were organized in tables and graphs, which were calculated in Excel - Microsoft Office ${ }^{\circledR} 2013$.

\section{Results and Discussion}

In the data collection period, the HU performed 984 surgeries elective Oncological scheduled between July 2015 and July 2016. Of these, 423 (43.4\%) were canceled, as described in Tables 1 and 2.

Table 1. Mortality from malignant neoplasms of the head and neck according to sex and age. Alagoas, Brazil. 2010-2014.

\begin{tabular}{|l|c|c|c|c|}
\hline \multirow{2}{*}{ Category } & \multicolumn{2}{|c|}{ Scheduled } & \multicolumn{2}{c|}{ Canceled } \\
\cline { 2 - 5 } & N & \% & N & \% \\
\hline Gender & & & & \\
Masculino & 367 & 37,2 & 168 & 45,9 \\
Feminino & 617 & 62,7 & 195 & 31,7 \\
\hline Shift & & & & 32,3 \\
Morning & 800 & 81,3 & 258 & 29,8 \\
Afternoon & 184 & 18,6 & 55 & \\
\hline
\end{tabular}




\begin{tabular}{|l|c|c|c|c|}
\hline Days of week & & & & \\
Monday & 202 & 47,7 & 85 & 42 \\
Tuesday & 183 & 43,2 & 72 & 39,3 \\
Wednesday & 218 & 51,5 & 111 & 50,9 \\
Thursday & 185 & 43,7 & 65 & 35,6 \\
Friday & 196 & 46,3 & 90 & 45,9 \\
\hline Total & $\mathbf{9 8 4}$ & $\mathbf{1 0 0 , 0}$ & $\mathbf{4 2 3}$ & $\mathbf{1 0 0 , 0}$ \\
\hline
\end{tabular}

Source: Sistema MV, 2016.

Table 1 describes the cancellation fee of surgery, 43.4\%, representing a high rate when compared to other studies, showing values between 6.2 to $35 \%$ [12-14]. According to Cavalcante et al [15] are required further investigation in this area in order to know the causes and the reasons that determine the suspensions. A teaching hospital of the Pakistan province had about $25 \%$ of their scheduled surgeries suspended [16].

In addition, the total study period, 367 surgeries scheduled in male patients, $168(45.9 \%)$ were canceled; and 617 female, the total suspension was 195 (31.7\%). This can be attributed to a greater concern of women with regard to health, since there was a significantly higher number of markings for this gender.

The surgeries scheduled in the morning totaled 800, with $258(32.3 \%)$ canceled, while among the 184 scheduled for the afternoon shift, there were 55 (29.8\%) suspensions. This result is consistent with other studies that observed a predilection of the surgical team for the morning hours, resulting in a much higher schedule for this period. Thus we observe a higher rate of cancellation this turn, since they were scheduled without prior planning sector capacity $[17,18]$

In the analysis of the day designated for each surgery the entire period, there was greater scheduling and cancellations on Mondays to Wednesdays. Mondays and Wednesdays are days that there are a greater flow of oncological surgical team in the operating room of the University Hospital, it brings consequences as a schedule up service capacity. Thus, a significant number of surgeries are suspended for reasons mainly related to the hospital organization. Friday, although there is a high rate of scheduled procedures, is a day with numerous cancellations. This is consistent with other studies where it is clear that these cancellations are mainly for lack of anesthesiologist or surgeon [19].

Each institution should establish specific measures to reduce, increasingly, surgery cancellation rate in their service. In our institution for purpose of reducing these numbers, however, due to the lack socioeconomic, patients are admitted without presenting the optimal clinical conditions for surgery.

In a review conducted on the production of nursing Surgical Center [20], the main subjects studied were the care and safety of adult patients, the role of management and nursing care, surgical discipline teaching at the undergraduate and the factors affecting the health Surgery Center team. Table 2 describes the causes of the surgery cancellations in the period studied.

Table 2: Surgeries canceled by cause during the period from July 2015 to July 2016. Alagoas, Brazil, in 2016.

\begin{tabular}{|l|c|c|}
\hline \multicolumn{1}{|c|}{ Causes } & N & \% \\
\hline Related to patient & $\mathbf{2 6 9}$ & $\mathbf{6 3 , 6}$ \\
No appear & 158 & 37,4 \\
Clinical unfavorable conditions & 104 & 24,81 \\
Refusal to achieving & 7 & 1,35 \\
\hline Related to hospital organization & $\mathbf{3 6}$ & $\mathbf{8 , 5}$ \\
Urgent surgery & 13 & 3,1 \\
Lack of bed & 17 & 4,2 \\
Lack of document/exam & 6 & 1,2 \\
\hline Related to human resources & $\mathbf{4 0}$ & $\mathbf{9 , 5}$ \\
Lack of anesthesiologist/surgeon & 37 & 8,7 \\
Change of conduct & 3 & 0,8 \\
\hline Related to materials and equipment & $\mathbf{7 8}$ & $\mathbf{1 8 , 2 9}$ \\
Lack of materials and/or medications & 75 & 17,9 \\
Ignored & 3 & 0,39 \\
\hline Total & $\mathbf{4 2 3}$ & $\mathbf{1 0 0 , 0}$ \\
\hline
\end{tabular}

Source: Sistema MV, 2016.

Regarding the reason for canceling the surgical procedure, we can see in Table 2, $269(63.6 \%)$ surgeries were canceled for issues related to the patient. Among them, more than 50\% refers to no user attendance. This clearly demonstrates a deficit in relation to a surgical system or confirmation guidance to users. Studies report that, due to the large gap between the date of the consultation and the day of surgery, a large number of patients 
do not remember the date of scheduling your surgery [21]. Other studies [22,23] also show that surgery causes suspension are strongly linked to factors intrinsic to the patient.

There are studies that recommend other actions to minimize the cancelation rate [24], as the preambulatory visit, in addition to improving communication between the institution and users; confirmation of the date of surgery in the coming days the procedure; performing outpatient preanesthesic; monitoring indicators in order to manage the problems; and creation of study groups for assistance of higher quality and humanized [24].

About $18.2 \%$ (78) of the procedures were canceled for causes related to materials and equipment. This high shortage of materials and medicines in this study, is a reality observed in numerous public hospital institutions. However to avoid such cancellations, which bring many inconveniences for the patient and their families, if an effective provisioning by management is required.

\section{Conclusion}

Surgical removal brings many consequences for the patient, who is preparing exciting and plans with his family to undergo surgery, as for hospital excusing human and material resources in pursuit of increasing their surgical indicators.

In this study, the number of canceled surgical procedures was high, and mostly female. Mondays, Wednesdays and Fridays - fairs, the morning shift, configured times where more surgeries were suspended due to lack of institutional organization at the time of scheduling. The failure of patients was the main reason for such suspensions.

Suspensions can and should be controlled and restricted., Is recommended in the first instance, the awareness of everyone involved in such a situation to which seeks a reduction in suspension rates and subsequently joint efforts to implement measures to restrict the most of this event.

Thus, the implementation of a central schedule effectively configure an efficient strategy for further organization of surgical procedures, from the provisioning of the number of daily surgery, surgical confirmation to the patient 48 before the scheduled date.

Management measures can minimize the canceled surgeries for events that can be preventable. administrative and planning a redesign of team work processes involved bring increase in surgical indicators and improved quality of care in the institution.

\section{References}

[1]. Hoff PMG, Chammas R, Novis Y, et al (2013) Princípios de Oncologia Cirúrgica. In: Feig BW, Hsu C. Tratado de Oncologia. 1 ${ }^{\mathrm{a}}$ edição. São Paulo: Editora Atheneu, Capítulo 39:525-36.

[2]. Kowalski LP. Manual de condutas diagnósticas e terapêuticas em oncologia. 2. ed. São Paulo: Âmbito; 2002

[3]. Longo DL. Oncology and haematology. In: Braunwald E, Fauci AS, Kasper DL, Hauser SL, Longo DL, Jameson JL, editors. Harrison's - Principles of internal medicine. New York: McGraw-Hill; 2001. p. 43-58.

[4]. Shekelle PG, Pronovost PJ, Wachter RM, McDonald KM, Schoelles K, Dy SM, et al. The Top Patient Safety Strategies That Can Be Encouraged for Adoption Now. Annals of Internal Medicine. 2013;158 (5_Part_2):365-8.

[5]. Ronsmans C, Graham WJ. Maternal mortality: who, when, where, and why. Lancet. 368. England2006. p. 1189-200.

[6]. Sociedade Brasileira de Enfermeiros de Centro Cirúrgico, Recuperação Anestésica e Centro de Material de Esterilização. Práticas Recomendadas da SOBECC: Centro Cirúrgico, Recuperação Anestésica e Centro de Material de Esterilização. São Paulo: SOBECC; 2013

[7]. Ministério da Saúde. Secretaria Nacional de Organização e Desenvolvimento de Serviços de Saúde. Normas e padrões de construções e instalações do serviço de saúde. $2^{\mathrm{a}}$ ed. Brasília; 1978.

[8]. Mahajan RP. The WHO surgical checklist. Best Pract Res Clin Anaesthesiol 2011; 25:161-8

[9]. Mendes W, Moura MLO. Avaliação de eventos adversos cirúrgicos em hospitais do Rio de Janeiro. Rev Bras Epidemiol 2012; 15:523-35.

[10]. Ministério da Saúde (BR). Secretaria Nacional de Organização e Desenvolvimento de Serviços de Saúde. Normas e padrões de construções e instalações de serviço de saúde. 2 ed. Brasília (DF): MS; 1978.

[11]. Arieta CEL, Lira RPC, Nascimento MA, Temporini ER, Kara JN. Suspensão de cirurgia de catarata e suas causas Rev Saúde Pública 2011; 35(5): 487-9.

[12]. Landim, FM (in memoriam); Paiva, FDS; Fiuza, MLT et al. Análise dos fatores relacionados à suspensão de operações em um serviço de cirurgia geral de média complexidade. Rev. Col. Bras. Cir. vol.36 no.4 Rio de Janeiro July/Aug. 2009

[13]. Paschoal MLH, Gatto MAF. Taxa de suspensão de cirurgia em um hospital universitário e os motivos de absenteísmo do paciente à cirurgia programada. Rev Latino-am Enfermagem. 2006; 14(1):48-53.

[14]. Lira RPC, Nascimento MA, Temporini ER, Kara-José N, Arieta CEL. Suspensão de cirurgia de catarata e suas causas. Rev Saúde Pública. 2001; 35(5): 487-9.

[15]. Cavalcante JB, Pagliuca LMF, Almeida PC. Cancelamento de cirurgias programadas em um hospital-escola: um estudo exploratório. Rev Latino-am Enfermagem. 2000; 8(4):59-65.

[16]. Zafar A, Mufti TS, Griffin S, Ahmed A, Ansari JA. Cancelled elective general surgical operations in Ayub teaching hospital. J Ayub Med Coll Abbottabad. 2007; 19(3):64-6.

[17]. Vieira MJ. Causas e consequências da suspensão de cirurgia programadas em uma cidade do nordeste do País[dissertação]. Rio de Janeiro (RJ): Escola de Enfermagem Ana Nery/UFRJ; 1982.

[18]. Fonseca KA, Oliveira Júnior LB, Beraldo AF, Araújo DA. Indicadores hospitalares: monitoramento e análise do cancelamento das cirurgias pactuadas do HU/CAS - UFJF com o PRO-HOSP. HU Revista. 2009;35(3):199-207.

[19]. Vanteenkiste, N. et al. Reallocation of operating room capacity using the due-time model. Medical Care, v. 50, n. 9, p. 779-784, 2012. <http://dx.doi.org/10.1097/MLR.0b013 e3182549eb9>. 
[20]. Campos JAR, Costa ACB, Dessotte CAM, Silveira RCCP. produção científica da enfermagem de Centro cirúrgico de 2003 a 2013. Rev. SOBECC, São Paulo. abr./jun. 2015; 20(2): 81-95.

[21]. Pesch, E.; Woeginger, G. Guest editorial to the special issue "Operations Research in Health Care". European Journal of Operational Research, v. 219, n. 3, p. 489-490, 2012. <http://dx.doi.org/10.1016/j.ejor.2011.11.001>.

[22]. Lira RPC, Nascimento MA, Temporini ER, Kara-José N, Arieta CEL. Suspensão de cirurgias de catarata e suas causas. Saúde Pública 2001;35(5):487-9.

[23]. Arieta CEL, Taiar A, Kara-José N. Utilização e causas de suspensão de intervenções cirúrgicas oculares em Centro Cirúrgico ambulatorial universitário. Rev Assoc Méd Bras. 1995; 41(3):233-5.

[24]. Cavalcante JB, Pagliuca LMF, Almeida PC. Cancelamento de cirurgias programadas em um hospitarescola: estudo exploratório. Rev Latino-am Enfermagem 2012 julho-agosto; 8(4):59-65. 